\title{
THE ECONOMIC CRISIS - THE TRIAL MOMENTS OF OUR SOCIETY
}

\author{
Prof. Ph.D. Adrian IGNAT, \\ Faculty of Theology and Sciences of Education, \\ Valahia University of Târgoviște, \\ ROMANIA \\ E-mail: adrianignat1974@yahoo.com
}

\begin{abstract}
This article tries to underline the economic crisis which is faced the world today and the individualistic idea of living without God and the conscience of God presence in this world. Human being must understand that we are living here, in the world, as a community and communion, being connected one with another. For that it is important to save all resources, being in solidarity with entire world. The paper analyses the French Revolution, as the start of individualism on society understanding, and continues with actual economic crisis with its involvement on our society and our life. The Orthodox Church proposes an important paradigm which can be used on our society. This model emphasises the Christian solidary and love, as our Lord Jesus Christ taught us.
\end{abstract}

Keywords: economic crisis; Orthodox Church; individualism; solidarity; consumption;

\section{INTRODUCTION}

The current crisis has created panic and mischief in people's lives. Faced with huge debts, the general economic collapse, and personally, some of our fellows have given up. Searching for financial stability has become the expression of many worries. Forced execution and the loss of all agonizing were hard times in the lives of those closest to us.

Under these conditions, those affected by the crisis (unemployed or drastically diminished salaries) reacted differently. Some have sought to find their way into spiritual values, in eternal values, in faith in God. Others who have been so despised by the lack of a real solution to real problems have become indifferent to spiritual values, seeking to solve only the material one. That is why depression and suicide have multiplied ${ }^{1}$. Against the backdrop of material shortages, this category has become more and more numerous. The religious man died, and in his place the material (economic) man grew up and consolidated, with all its consequences.

\section{THE FRENCH REVOLUTION AND ITS EFFECTS}

The notion of light, as it was understood in that time, can be found in various combinations: luminism and light, freedom and light; "to light is to remove the various veils and envelopes in front of the eyes, to make room for light in the intellect and in the heart, so that it illuminates and heats it, as well as entering into the realm and order of the fields,

\footnotetext{
${ }^{1}$ Sorin M. Rădulescu, „Sinuciderea în Europa, în contextul crizei economice globale” [Suicide in Europe in the context of the global economic crisis], în Revista Română de Sociologie, XXIII (2012), nr. 5-6, pp. 385-403.
} 
where tones the fulfilment of man and true happiness?" Wieland praises any contribution to the "national economy, politics, civil and military constitution, religion, morals, public education, science and the arts, crafts and agriculture, which spreads some light in every part of our homeland."3

The Age of Lights ${ }^{4}$ represents a turning point for the history of mankind and the history of the Christian Church. For the West, enlightenment "meant the clear division between religion and the field of public life, that is, the first and deepest rupture between Christianity and Europe. ${ }^{5}$ The French Revolution is the hardest expression of secular society towards Christian religion". "The French Revolution (1789) was one of the highlights of the Enlightenment period. One of the goals that Enlightenment has proposed was the eradication of occultism and its practices."7

The attempts to humanize and democratize the world, decreed by the age of lights, are based not on Christian humanism, but on the influence of secular humanism. "Because of enlightenment, man managed to record victories beyond the eighteenth century, known as the century of lights, to dominate the outer nature through the prestigious development of science and technology, but he also became the slave of his own passions in his being, that can no longer control". "The victory of the French Revolution also meant the categorical separation of the State Church. On the other hand, the events of 1789-1794 "gave birth to capitalism, economically; the preponderance of the bourgeoisie in the social and political order; and the ideological values that are supposed to be its own." 9

Replacing feudalism with capitalism was a development for European society, marked in particular by the rise of a new social class - the bourgeoisie - and the entrance into a shadowy cone of the great landowners. At the same time, the Western Church passes through convulsions marked by the anti-clerical attitude of the revolutionaries. During the French Revolution, Christianity was declared "dangerous superstition" and was outlawed (November 1793). ${ }^{10}$

The end of the Middle Ages and the beginning of the age of lights brought about dramatic changes in Western Christianity. "Religious individualism and subjectivism, preached by Protestantism, led to the multiplication of confessions, to doubt and inner disintegration, to endless and sterile discussions that caused the pietistic reaction. The progress of physic-mathematical science in the seventeenth century, as well as the flourishing of Cartesian philosophy and empiricism or English Gnosticism, eventually led to

\footnotetext{
${ }^{2}$ Ulrich Im Hof, Europa luminilor [Europe of lights], traducere de Val Panaitescu, Editura Polirom, Iaşi, 2003, p. 9.

${ }^{3}$ Cf. ibidem, p. 11.

${ }^{4}$ To be seen M. Vovelle, Omul luminilor [Man of the lights], Editura Polirom, Iaşi, 2000.

${ }^{5}$ Pr. Dr. Nicolae Achimescu, Religii în dialog [Religions on dialogue], Editura Trinitas, Iaşi, 2006, p. 395.

${ }^{6}$ In its most eccentric form, inspired by J.-J. Rousseau, the laicism of the French Revolution, converted into civil religion, had Robespierre as the ultimate sacerdot and transformed Reason into Goddess of the Republic. Cf. M. Ozouf, La fête révolutionnaire, Gallimard, Paris, 1976; J. Starobinsky, 1789: Emblemele raţiunii [1789: The emblems of reason ], traducere de I. Pop, Editura Meridiane, Bucureşti, 1990.

${ }^{7}$ Pr. Dr. Nicolae Achimescu, Noile mişcări religioase [New religious movements], Editura Limes, Cluj-Napoca, 2004, p. 41.

${ }^{8}$ Pr. Prof. Dr. Dumitru Popescu, Hristos, Biserică, Societate [Christ, Church, Society], Editura Institutului Biblic şi de Misiune al Bisericii Ortodoxe Române, Bucureşti, 1998, p. 16.

${ }^{9}$ François Furet, Reflecţii asupra revoluţiei franceze [Reflections on the French Revolution], traducere de Mircea Vasilescu, ediţia a II-a, Editura Humanitas, Bucureşti, 2011, p. 35.

${ }^{10}$ Pr. Ioan Bizău, Viaţa în Hristos şi maladia secularizării [Life in Christ and the disease of secularization], Editura Patmos, Cluj-Napoca, 2002, p. 267.
} 
deism, naturism, monadology, scepticism and sensualism, free thinking French encyclopaedists and materialists, and even from here to hate the Church" ${ }^{\text {. }}$.

Together with the many secular decisions taken during the French Revolution, a church restoration was achieved through its liberation from the state. Still now, the old sins have been removed, which brought heavy to the service of the Church and to Christianity: the recruitment of bishops only among nobles and landowners, the exaggerated domination of the Jesuits, etc. The abolition or suspension of papal privileges was again a necessary action. "The awakening of interest in the ethnography and religion of pagan peoples and the giant evangelistic work are a result of this historic process so decisive in the history of humanity" 12 .

The French Revolution was about to destroy French Catholicism. However, the Church survived, but remained for a long time marked as a mortal trauma. Analysing the impact of the French Revolution and Enlightenment on the Catholic Church, Antonio Rosmini, in his manifesto entitled Delle cinque piaghe della Santa Chiesa, speaks of the five wounds in the body of the Church: the distance between the clergy and the people; the insufficiency of clergy education; the separation of bishops; the appointment of bishops by state power; the service of church goods ${ }^{13}$. On these issues, the Catholic Church will have a position through the encyclical of Pope Leon XIII, Rerum novarum. It will accept the distinction between ecclesial society and civilian sovereignty, recognize the diversity of nature and purpose, and the autonomy and legitimacy of political power, while insisting on the ideal of harmony between the two societies and powers.

\section{THE ECONOMIC CRISIS - THE EMINENTLY MORAL CRISIS OF SOCIETY}

In an article published in the Theological Magazine, Nicoleta Acatrinei points out that "The economic man was born in the middle of the nineteenth century and had as a father the utilitarian philosopher Bentham and as a «mother» the Ricardian economy strengthened and developed by John Stuart Mill". ${ }^{14}$ Following this symbiosis, a purely theoretical construction was created ${ }^{15}$. "The last economic abstractions that are economic laws are based on a prior abstraction of man, the economic man. The statement "man is motivated by desire for wealth" can be considered as an implicit definition of the term "economic man»"16. In Mill's view, no other facet of human nature is analysed, and this ,not because any economist would be so stupid to think that humanity would have done so, but because it is the road that science necessarily needs to follow... The way in which the political economy proceeds necessarily is to regard this primary and acknowledged goal

${ }^{11}$ Pr. Prof. Dr. Ioan Rămureanu, Pr. Prof. Dr. Milan Șesan, Pr. Prof. Dr. Teodor Bodogae, Istoria Bisericească Universală [Universal Church History], vol. II, Editura Institutului Biblic şi de Misiune al Bisericii Ortodoxe Române, Bucureşti, 1956, p. 262.

12 Ibidem, p. 266.

${ }^{13}$ Cf. Ioan I. Ică jr., „Biserică, societate, gândire în Răsărit, în Occident şi în Europa de azi” [„,Church, Society, Thought in the East, in the West and in Europe today"], în vol. Gândirea socială a Bisericii, Editura Deisis, Sibiu, 2002, p. 31.

${ }^{14}$ Nicoleta Acatrinei, „Sfântul Ioan Gură de Aur şi homo oeconomicus: de la etică la morală” [„St. John Chrysostom and homo oeconomicus: from ethics to morality"], în Revista Teologică, XVII (2007), nr. 4, p. 168.

${ }^{15}$ K. Pribam, Les fondements de la pensée économique, Editura Economică, Paris, 1986, p. 175.

${ }^{16}$ J. S. Mill, Sur la définition de l'économie politique; et sur le méthode d'investigation qui lui est propre, Michel Houdiard Editeur, Paris, 2003, p. 22. 
(the accumulation of wealth) as if it were, from all the comparable hypotheses in simplicity, the closest to the truth" ${ }^{\text {"17. }}$.

The accumulation of wealth is thus the desideratum of an age that no longer focuses on spiritual goods, but only on material assets. The crisis of today's society is characterized by: blind obsession for money; the pre-eminence of selfishness; proliferation of lack of sincerity; family decay as a social institution; the public outbreak of sexuality; increasing discord; the amplification of conflicts of all kinds (among individuals, among individuals and society, among social groups, among generations) etc. The man of today is lonely and empty, it is free of landmarks, it is "the object of manipulation" and of antimods" that deepen the value crisis, no longer recognizes itself, is deceived by the illusion of false values. ${ }^{18}$ „The current economic crisis is not only global but also systemic. This is a crisis of values, a crisis of prospects. History has definitely demonstrated that the possibility of solving the political, economic and humanitarian problems of the modern world must be sought not only in the redistribution of material resources or in the improvement of their management technologies, but also in the spiritual sphere. The first cause of this crisis is the degradation of moral-ethical motivation from economic activity, that is, the loss of the main purpose in the economy, namely to build a harmonious and equitable society in which man can realize his professional or spiritual potential regardless of the social position or his political beliefs." 19

Faced with the most diverse and sophisticated challenges, mankind has gone through the centuries a road that has unfortunately not approached God but has removed it. Secularization, globalization, atheism, agnosticism, hedonism are only a few of the phenomena facing the present society. Searching for the meaning of existence has become important in a senseless world. That is why today, when we are confronted with an acute economic crisis, we find that, in fact, we are facing a crisis of values, models, life itself. This is all the more interesting, as all these shortcomings come to light when society is confronted with material gaps, when the economic market is felt as a result of major financial disasters generated by greed and avarice, lack of scruples and deliberate ignorance your own conscience, lack of character and dignity, servility and misery, etc. These social races, deeply sown in many of our fellows, have resulted in a continuous degradation of the personal and social moral life, the perspective of Christian living. "The essence of the moral crisis consists, of course, in the diminution of religiosity" 20 .

The problem of "model crises" has become important also for many specialists. However, the conclusions are divergent. In the literature, three main types of models are analysed: simple models, imitated by attempts and errors; scientific models that we try to reproduce by assimilating the principles of action and behavioural norms; ethical models that are imitated by value criteria and which awaken in enthusiasm, passion, aspirations, high spiritual orientation $^{21}$. All historical periods have faced challenges and crises. Mankind was not and will not be free of "crises". Each generation considered that the crisis was the

\footnotetext{
${ }^{17}$ Ibidem, p. 23.

${ }^{18}$ Prof. univ. dr. Anca Borza, Conf. univ. dr. Mirela Popa, Lect. univ. dr. Codruţa Osoian, „ «Criza de model moral» - o realitate?” [,„«Moral pattern crisis» - a reality?”], în Management \& marketing, http://www.managementmarketing.ro/pdf/articole/47.pdf, p. 46.

${ }^{19}$ Cf. www.teologia-sociala.ro. The original can be found on the official website of the Moscow Patriarchate, www.mospat.ru.

${ }^{20}$ Ibidem.

${ }^{21}$ Constantin Enăchescu, Tratat de psihologie morală [Treatise of moral psychology], Editura Tehnică, Bucureşti, 2005, p. 230.
} 
hardest and the biggest effects for that time. The economic crisis implies "the manifestation of difficulties or periods of tension, of disturbance, of attempts that manifest in the society" 22 .

Having its starting point in the US in 2007, the current economic crisis has spread rapidly across Europe and from here across the world. Increasing the degree of indebtedness to banks for satisfying various needs or pleasures has led to the inability to pay the contracted loans ${ }^{23}$. All these toxic credits have in turn led to a chain-fall of financial institutions, economic actors, and so on.

However, the current economic crisis, with the exception of its negative aspects, has brought with it benefits. We have realized that any economic prosperity ends at one point, that ethics, defined and appropriated in everybody's sense, is more important than price or product policy. The global, national or regional economy would be much more profitable if it were ethical in advertising policy, in sales, in the treatment of employees, partners and clients. Aristotle, speaking in the context of his time, exemplifies this by saying: "By guitar singing someone becomes for instance a good guitarist as well as evil and in the same way with the architect and any craftsman or artist. Whoever builds well becomes a good architect, and who builds evil, a bad architect. If that were not so, no teacher would need it, but everyone would come to the world master or scribe. Even so there are the things and the virtues. Through our behaviour in new business relationships we become righteous or unjust; by acting in danger and by the habit of fearing them or resisting them, we become valiant or cowards. And that is also the case with lust or anger: some become sober and idle, others unafraid and angry, as they do in some cases (...). And that is why it is not so important if we get used to this or that; on the contrary it means very much or better said everything" ${ }^{24}$.

The economic means to acquire the necessary for life or, in the case of many, to satisfy our own pleasures, must not constitute real goals for our life. If originally money represented only one currency of exchange, then they became an aim in itself. Despite this, the Church does not want and "does not accept the separation of the human economy, the development of the civilization in which it is inserted. What matters is man, every man, every group of people, the whole of mankind" 25 .

The people summarized in a dictum the whole attitude about wealth or poverty, the position in society or the prestige held: "To be a gentleman is a chance to be human is a great thing." As a result, in the economy, as in the other spheres of life, ethics must be the human conduct of welfare. "When man is aware of the fundamental values of life, true beauty and riches, he approaches pure science with a prophylactic, therapeutic and vitamin effect on mind and soul"26.

What characterizes man, his humanity itself, must be the foundation of human relationships. An important aspect of our relationships with our fellows is our human

$22 * * *$, Dicţionarul explicativ al limbii române [The explanatory dictionary of the Romanian language], http://dictionare.edu.ro/definitie/criz\%C4\%83; Jean Marie Albertini, Ahmed Silem (eds.), Lexique d'économie, Dalloz, Paris, 1999.

${ }^{23}$ Banks have also borrowed low-income persons who have been unable to repay the loans, and so the phenomenon of "crise des subprimes" appears.

${ }^{24}$ Aristotel, Etica nicomahică [Nicomahic ethics], Editura Antet, Bucureşti, 2002, p. 38.

${ }^{25}$ L. J. Lebret, Dynamique concrète du dèvelopement. Économie et Humanisme, Les Éditions Ouvrières, Paris, 1961, p. 28.

${ }^{26}$ Cosmin Stoica, Consideraţii privind importanţa eticii creştine în viaţa economică [Considerations on the importance of Christian ethics in economic life], http://atreiafortaromaniaprofunda.blogspot.ro/2011/02/consideratii-privind-importanta-eticii.html 
solidarity. Solidarity is a feature that refers not only to individuals but also to international economic policies. Within the framework of solidarity, man meets the one next to him, discovers him, discovers himself and discovers God. From this, the wealthy should learn and apply in their relations with the disadvantaged, the poor, the sick, the helpless. Some of them, however, "stubborn in their avarice, will only be able to provoke the judgment of God and the wrath of the poor, with unpredictable consequences. Closing themselves in the shell of their own egoism, the presently thriving civilizations will end up destroying their highest values, sacrificing the will to be the desire to have more"27.

In order to address the current economic crises, several considerations have been issued within the Christian Church. Paul Heyne believes that Christian economists are "fleeing an illusion", because it is not "a single Christian vision in the economic order", and that is why Christian economists "should leave their theology at home", when they try to deal with economic issues and makes public a Christian statement on economic policy ${ }^{28}$. Webb synthesizes Heyne's position as follows: "We should be good economists and offer a policy of choice: we should be both Christians and live in obedience to the radical commandments of the New Testament. But attempts to mix the two will not lead us to the pursuit of unity...." ${ }^{29}$. Atherton ${ }^{30}$ believes, like Heyne, that all Christians have adopted a variety of views on the value of the market economy from radical criticism to moral support. However, Atherton does not understand the complexity of how markets operate, as well as their broad social implications. In the opinion of other researchers, placing Christian values above the market, not the association of free market values with Christian social ethics, is the way the current crisis is resolved. On the basis of these considerations, Hay ${ }^{31}$ will propose "seeking interim solutions", 32 .

On the other hand, all economic specialists are looking to come up with the most ingenious solutions, ranging from encouraging consumption, to reducing financial deficits and emerging $\mathrm{debt}^{33}$. However, only by adopting Christian solutions, love for God and

\footnotetext{
${ }^{27}$ Paul al VI-lea, The encyclical letter Populorum progressio, nr. 49.

${ }^{28}$ Paul Heyne, „Christianity and the Economic Order”, in Bulletin of the Association of Christian Economists, 15 (Spring), 5-6, 1990.

${ }^{29}$ Bruce G. Webb, „Whose theology? Which economics?”, in Bulletin of the Association of Christian Economists, 23 (Spring), 1994, p. 50.

${ }^{30}$ John Atherton, Christianity and the Market: Christian Social Thought for Our Times, SPCK, London, 1992.

${ }^{31}$ Donald A. Hay, „On being a Christian economist”, in (eds.) Donald A. Hay and Alan Kreider, Christianity and the Culture of Economics, University of Wales Press, Cardiff, 2001, pp. 166-190.

${ }^{32}$ Cf. Andrew Henley, Swansea University, Doing economics as a Christian - constructive engagement or prophetic detachment?, Cambridge, 2004, http://www.christian-economists.org.uk/jour34_Henley.pdf, p. 5.

${ }^{33}$ Lecturer. PhD. Ioana Lupasc, Faculty of Economics and Business Administration, "Dunarea de Jos" University, Galati (Romania), proposes the following solutions:

- to promptly and accurately inform the actors involved (population, economic agents) of the risks associated with lending activity by creating crisis scenarios, as the current crisis was largely due to the failure to pass on the necessary information on all associated risks;

- elimination of waste by reducing administrative budget expenditures, but not by reducing the salaries of the public sector by $25 \%$ as it did in Romania, but by creating a viable plan that would allow the crisis to exit; in practice, an effective analysis of budget expenditures was required to eliminate inefficient or low efficiency spending. We believe that the most effective investment is in human capital, youth, or education. In Romania, this investment has not been supported;

- recapitalization of affected public or private institutions, especially banks; the Basel III Agreement provides for global capital adequacy standards, better risk coverage and liquidity standards for banks;

- creation of new jobs, both by private economic agents and by the state, by attracting investments;

- investment plan in public infrastructure;
} 
neighbour, we will succeed in removing poverty and illiteracy from society, we can cultivate value and faith, life and not death. ${ }^{34}$ Fasting, praying, as well as serving together can bring many benefits for every person and for society as a whole. ${ }^{35}$

The courage of the confession of Christ must manifest itself in every field of activity: politics, economy, education, culture, etc. Only in this way can human society heal its illnesses and temptations. The transition from the consumer society to the assume society, i.e., "the society that assumes the realities that are driven by reason, creates an inner human balance between reason, indolence and lust" 36 , may be a current way of life.

From the theological-theoretical point of view, the word econom, iconom (that is, the one that saves money) refers to the spiritual guide, who manages the spiritual ones, keeping the human nature within its limits. Instead, the present society understands by economic means the preaching of consumption, the satisfaction of desires and pleasures, without limits. As a result, the exit from the crisis can not be achieved by consuming, because consumption means material and spiritual exhaustion of resources and life. For the real exit from the crisis is necessary repentance - metanoia - change of mind, mentality from the service of bodily pleasures, to the service of God. "So the bridge from the consumer society to the assimilation society is repentance, the mind enlightened by grace, through their pure life, with professional training. So society can enter the road of peace, having a peaceful life. ${ }^{, 37}$

The Orthodox Church has repeatedly stressed, through the voice of its representatives, that today we are actually confronted with an eminently moral crisis that also presents itself as an economic one. This is all the more important, especially as with the identification of the causes of the current crisis, we will know what measures we need to take to succeed in combating it. „The economic-financial and socio-moral crisis has shaken our world, calling for meditation and change, for transfiguration and renewal, for, as we

- creating social programs and related investments;

- tax reform, but it must be taken into account that by referring to the Fiscal Code, it should not be changed / changed too often, as is the case in Romania, because certain stability must be ensured and guaranteed in the fiscal field;

- at individual level - strictly organizing and observing a personal budget, which means that only expenditures of strict necessity must be made. To be seen Lect. $\mathrm{PhD}$. Ioana Lupaşc, „O provocare a societăţii moderne: criza economică. Remedii din perspectivă creştină” [,A challenge for modern society: the economic crisis. Remedies from a Christian perspective"], în Călăuza creştină, Revista Arhiepiscopiei Dunării de Jos, http://www.calauza.edj.ro/?p=3312.

34 „Economists assess the laws of the market to see if they work properly, but the Church describes the theological frameworks within which man will move, propose spiritual goals, and comfort the wounds of men, using wine and oil, materials that truly cleanse, healing the wounds as we do shows the evangelical parable of the good Samaritan".***, Consideraţii teologice referitoare la criza economică. Scrisoare circulară citită $\hat{\imath}$ parohii şi mânăstiri la 21 martie 2010 [Theological considerations regarding the economic crisis. Circular letter read in parishes and monasteries on 21 March 2010], la http://romaningermania.ro/mesajul-bisericiiortodoxe-din-grecia-cu-privire-la-criza-economica/

${ }^{35}$ „Abundance, well-being, over-consumption are the causes responsible for economic crises. Of course, it is important to live every "decent" in terms of material goods, but they all have their limits. Church life is closely

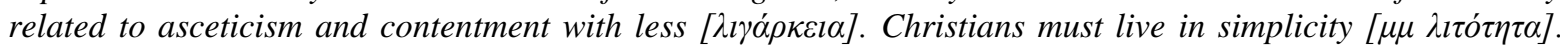
Unfortunately, however, the asceticism that underlies Christian life is not lived in hyper-consumerist societies. By saying ascetic, we understand the correct use of the material goods necessary for life and not the exacerbated accumulation and consumption". Ibidem.

${ }^{36}$ Pr. Conf. Dr. Petre Comşa, „Reflecţii ortodoxe la criza financiară şi economică” [„,Orthodox Reflections on the Financial and Economic Crisis”], în Almanah bisericesc, Arhiepiscopia Târgoviştei, 2010, p. 66.

${ }^{37}$ Ibidem. 
know, this negative phenomenon causes an intensification of searches, a profound existential evaluation offers the germs of building a new world with the hope of a more beautiful, better and more straightforward paradigm of true Christian civilization",38

Structured profoundly on promoting the purely economic values, personal financial possibilities, the current society is facing an acute crisis of values. Those who have enough capital are often not very well educated intellectually or do not want to make a positive change in the lives of others, but only in their own lives. Personal account and material availability are the targets for such people. For them there are no scruples, Christian morals or professional ethics. For them money is the supreme master to worship ${ }^{39}$.

The creation of such capitalism, a ferocious capitalism, with serious implications in social life, disrupts the meaning of human existence, the natural movement of man and the world towards their Creator. Faced often with such challenges, with secularism and globalism, with the desire for an accentuated consumerism, the Orthodox Church tried to adapt its mission and pastoral work. "The Orthodox Church is the first to keep up the sense of social solidarity. Struggling with the mentality of the old slavery and feudal society, she (the Church) taught her believers to temper their individualism and selfishness and to subordinate their personal interests to the general interest of the society in which man is integrated" 40 .

The awareness of one's own mission and the attempt to respond to the spiritual and material needs of the present world has led the Church of Christ to take an attitude, seeking man's recitation not of emerging material needs, but of perennial spiritual needs. The awareness of one's own mission and the attempt to respond to the spiritual and material needs of the present world has led the Church of Christ to take an attitude, seeking man's recitation not of emerging material needs, but of perennial spiritual needs. "In this situation of economic greed without ethics, when everything becomes uncertain and unpredictable, changing and deceiving, it is necessary to increase prayer, to draw closer to God, the steadfast and implacable, just and merciful, but also to increase vigilance and prudence in order not to be deceived. Although the financial and economic crisis is largely a harsh immanent judgment for too much greed of material things gathered unjustly and too much waste of money, it can still be understood and used as a call for a new beginning in the lives of people and peoples. Thus, the economic crisis leads us to be more economical and more rigid, not to put our hope in material values, money and wealth more than in the spiritual values of faith, justice, fairness, and solidarity with those in need"41.

In a word addressed to representatives of all religions in Europe, Patriarch Daniel, making a brief analysis of the current economic crisis faced by the world, said: "The current economic crisis requires Member States and all European citizens to moderate and vigilant in using money, and calls on the European Union to progress in wisdom and solidarity, that

\footnotetext{
38 † IPS Nifon, Arhiepiscop şi Mitropolit al Târgoviştei, „Perspectiva ortodoxă asupra misiunii şi dialogului ecumenic" [„,The Orthodox Perspective on Ecumenical Mission and Dialogue”], în Decernarea titlului de Doctor Honoris Cause Inaltpreasfinţitului Părinte Prof. Univ. Dr. Nifon Mihăiţă Arhiepiscop şi Mitropolit, Târgovişte, 11 iulie 2013, p. 32.

${ }^{39}$ Pr. Lect. Dr. Sorin Şelaru, Pr. Lect. Dr. Patriciu Vlaicu (coord.), Misiunea sacramentală a Bisericii Ortodoxe in context european [The sacramental mission of the Orthodox Church in a European context], Editura Basilica, Bucureşti, 2013, coperta 4.

${ }^{40}$ Pr. Prof. Dr. Dumitru Popescu, Hristos, Biserică, societate [Christ, Church, Society], p. 22.

41 † PF Daniel, Patriarhul Bisericii Ortodoxe Române, Predică la Duminica a XXXII-a după Rusalii (a lui Zaheu) [Preaching on Sunday, XXXII after Pentecost (Zaheu)], http://www.basilica.ro/stiri/patima-lacomiei-deavere 3494.html.
} 
is to respond to new problems emerging as major tensions between the economic crisis and political credibility, between austerity policies and the need for economic growth, between individual freedom and social solidarity, between national identity and global unity, between tradition and secularization, between family crises and diminishing birth rates, between the crisis of spiritual life and the degradation of social life" ${ }^{\text {"42 }}$.

\section{BIBLIOGRAPHY:}

[1] ***, Considerații teologice referitoare la criza economică. Scrisoare circulară citită în parohii şi mânăstiri la 21 martie 2010 [Theological considerations regarding the economic crisis. Circular letter read in parishes and monasteries on 21 March 2010], la http://romaningermania.ro/mesajulbisericii-ortodoxe-din-grecia-cu-privire-la-criza-economical

[2] ***, Dicţionarul explicativ al limbii române [The explanatory dictionary of the Romanian language], http://dictionare.edu.ro/definitie/criz\%C4\%83

[3] Acatrinei, Nicoleta, „Sfântul Ioan Gură de Aur şi homo oeconomicus: de la etică la morală” [,St. John Chrysostom and homo oeconomicus: from ethics to morality"], în Revista Teologică, XVII (2007), nr. 4

[4] Achimescu, Pr. Dr. Nicolae, Noile mişcări religioase [New religious movements], Editura Limes, ClujNapoca, 2004

[5] Achimescu, Pr. Dr. Nicolae, Religii în dialog [Religions on dialogue], Editura Trinitas, Iaşi, 2006

[6] Albertini, Jean Marie - Silem, Ahmed (eds.), Lexique d'économie, Dalloz, Paris, 1999.

[7] Aristotel, Etica nicomahică [Nicomahic ethics], Editura Antet, Bucureşti, 2002, p. 38.

[8] Atherton, John, Christianity and the Market: Christian Social Thought for Our Times, SPCK, London, 1992.

[9] Bizău, Pr. Ioan, Viața în Hristos şi maladia secularizării [Life in Christ and the disease of secularization], Editura Patmos, Cluj-Napoca, 2002

[10] Borza, Prof. univ. dr. Anca - Popa, Conf. univ. dr. Mirela - Osoian, Lect. univ. dr. Codruța, „«Criza de model moral» - o realitate?” [,„«Moral pattern crisis» - a reality?”], în Management \& marketing, http://www.managementmarketing.ro/pdf/articole/47.pdf, p. 46.

[11] Comşa, Pr. Conf. Dr. Petre, ,Reflecţii ortodoxe la criza financiară şi economică” [,Orthodox Reflections on the Financial and Economic Crisis"], în Almanah bisericesc, Arhiepiscopia Târgoviştei, 2010

[12] Daniel, $\dagger$ PF Patriarhul Bisericii Ortodoxe Române, Criza actuală $-o$ şansă pentru a progresa in inţelepciune [The current crisis - a chance to progress in wisdom], la http://www.basilica.ro/stiri/b2013-anul-cetateniei-europene-criza-actuala-o-sansa-pentru-a-progresain-intelepciuneb_7329.html.

[13] Daniel, $\uparrow$ PF Patriarhul Bisericii Ortodoxe Române, Predică la Duminica a XXXII-a după Rusalii (a lui Zaheu) [Preaching on Sunday, XXXII after Pentecost (Zaheu)], http://www.basilica.ro/stiri/patima-lacomiei-de-avere_3494.html.

[14] Enăchescu, Constantin, Tratat de psihologie morală [Treatise of moral psychology], Editura Tehnică, Bucureşti, 2005

[15] Furet, François, Reflecţii asupra revoluţiei francize [Reflections on the French Revolution], traducere de Mircea Vasilescu, ediţia a II-a, Editura Humanitas, Bucureşti, 2011

[16] Hay, Donald A., „On being a Christian economist”, in (eds.) Donald A. Hay and Alan Kreider, Christianity and the Culture of Economics, University of Wales Press, Cardiff, 2001

\footnotetext{
${ }^{42}$ Idem, Criza actuală - o şansă pentru a progresa în inţelepciune [The current crisis - a chance to progress in wisdom], la http://www.basilica.ro/stiri/b2013-anul-cetateniei-europene-criza-actuala-o-sansa-pentru-aprogresa-in-intelepciuneb_7329.html.
} 
[17] Henley, Andrew, Swansea University, Doing economics as a Christian - constructive engagement or prophetic detachment?, Cambridge, 2004, http://www.christianeconomists.org.uk/jour34_Henley.pdf

[18] Heyne, Paul, „Christianity and the Economic Order”, in Bulletin of the Association of Christian Economists, 15 (Spring), 5-6, 1990.

[19] Hof, Ulrich Im, Europa luminilor [Europe of lights], traducere de Val Panaitescu, Editura Polirom, Iaşi, 2003

[20] Ică jr., Ioan I., „Biserică, societate, gândire în Răsărit, în Occident şi în Europa de azi” [„,Church, Society, Thought in the East, in the West and in Europe today”], în vol. Gândirea socială a Bisericii, Editura Deisis, Sibiu, 2002

[21] Lebret, L. J., Dynamique concrète du dèvelopement. Économie et Humanisme, Les Éditions Ouvrières, Paris, 1961

[22] Lupaşc, Lect. $\mathrm{PhD}$. Ioana, „O provocare a societăţii moderne: criza economică. Remedii din perspectivă creştină” [,A challenge for modern society: the economic crisis. Remedies from a Christian perspective"], în Călăuza creştină, Revista Arhiepiscopiei Dunării de Jos, http://www.calauza.edj.ro/?p=3312.

[23] Mill, J. S., Sur la définition de l'économie politique; et sur le méthode d'investigation qui lui est propre, Michel Houdiard Editeur, Paris, 2003

[24] Nifon, $\uparrow$ IPS Arhiepiscop şi Mitropolit al Târgoviştei, „Perspectiva ortodoxă asupra misiunii şi dialogului ecumenic" [The Orthodox Perspective on Ecumenical Mission and Dialogue"], în Decernarea titlului de Doctor Honoris Cause Înaltpreasfinţitului Părinte Prof. Univ. Dr. Nifon Mihăiţă Arhiepiscop şi Mitropolit, Târgovişte, 11 iulie 2013

[25] Ozouf, M., La fête révolutionnaire, Gallimard, Paris, 1976;

[26] Popescu, Pr. Prof. Dr. Dumitru, Hristos, Biserică, Societate [Christ, Church, Society], Editura Institutului Biblic şi de Misiune al Bisericii Ortodoxe Române, Bucureşti, 1998

[27] Pribam, K., Les fondements de la pensée économique, Editura Economică, Paris, 1986

[28] Rădulescu, Sorin M., „Sinuciderea în Europa, în contextul crizei economice globale” [,Suicide in Europe in the context of the global economic crisis"], în Revista Română de Sociologie, XXIII (2012), nr. 5-6

[29] Rămureanu, Pr. Prof. Dr. Ioan - Şesan, Pr. Prof. Dr. Milan - Bodogae, Pr. Prof. Dr. Teodor, Istoria Bisericească Universală [Universal Church History], vol. II, Editura Institutului Biblic şi de Misiune al Bisericii Ortodoxe Române, Bucureşti, 1956

[30] Şelaru, Pr. Lect. Dr. Sorin - Vlaicu, Pr. Lect. Dr. Patriciu (coord.), Misiunea sacramentală a Bisericii Ortodoxe in context european [The sacramental mission of the Orthodox Church in a European context], Editura Basilica, Bucureşti, 2013

[31] Starobinsky, J., 1789: Emblemele raţiunii [1789: The emblems of reason], traducere de I. Pop, Editura Meridiane, Bucureşti, 1990.

[32] Stoica, Cosmin, Consideraţii privind importanţa eticii creştine în viaţa economică [Considerations on the importance of Christian ethics in economic life], http://atreiafortaromaniaprofunda.blogspot.ro/2011/02/consideratii-privind-importanta-eticii.html

[33] Vovelle, M., Omul luminilor [Man of the lights], Editura Polirom, Iaşi, 2000.

[34] Webb, Bruce G., „Whose theology? Which economics?”, in Bulletin of the Association of Christian Economists, 23 (Spring), 1994.

[35] www.mospat.ru

[36] www.teologia-sociala.ro 